\title{
What is the Purpose of Trying to Discredit Liberalism and The Idea of Democracy?
}

\author{
Dzhamal Mutagirov*
}

Doctor of Philosophical Sciences, Russia

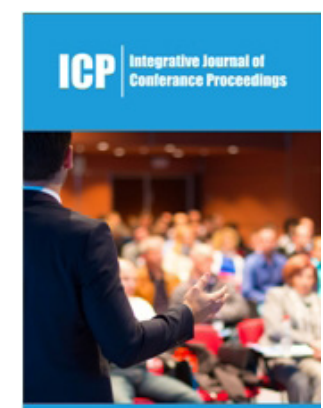

*Corresponding author: Dzhamal $\mathrm{Mu}-$ tagirov, Doctor of Philosophical Sciences, Russia

Submission: 海July 08, 2019

Published: 漈August 05, 2019

Volume 1 - Issue 5

How to cite this article: Dzhamal Mutagirov. What is the Purpose of Trying to Discredit Liberalism and The Idea of Democracy. Int J Conf Proc.1(5). ICP.000522.2019.

Copyright@ Dzhamal Mutagirov, This article is distributed under the terms of the Creative Commons Attribution 4.0 International License, which permits unrestricted use and redistribution provided that the original author and source are credited.

\section{Annotation}

World monitors the continued strengthening of the international tension and continuing attacks some countries 'governing elites' to each other with astonishment and concern. This occurs under soothing statements about "end of the cold war". The situation is like such of 1930 's when, supposedly, also "there wasn't any war" but, as Sir Winston Churchill [1] admitted later, "English-speaking peoples through their unwisdom carelessness and good nature allowed the wicked to rearm" [1-6]. The 75 anniversaries of the victory over fascism will be celebrated soon. Antifascist struggle had initiated the Global democratic revolution. Over the years, humankind has committed grand gallop forward, ended with colonialism, with external manifestations of racism, apartheid, had adopted the International Code of Human and Peoples ' Rights, committed scientific, technical, cultural, information and other revolutions. All this had enabled him to achieve very remarkable progress in all spheres of life. However, at the turn of the Millennia the story took an unexpected turn, the meaning of which remains an enigma. Using historical, logical and comparative methods allows to reveal the enigma.

Keywords: Liberalism; Absolutism; Republic; Democracy; Autocracy; Human rights; The rule of law

\section{Introduction}

According to philosophy, history develops in cycles and on the 'law of negation of negation'. Man craves some new, but the "new" often turns out to be worse than the old one. This is particularly noticeable in some Eurasian countries, where historical processes have taken the wrong trend - backwards to the Middle Ages. Their authorities are attempting to replace the republican form of governments with the absolutist and dictatorial. These actions, inevitably doomed for failure in the age of universal literacy and Global democratic revolution, are trying to enforce by resurrection and dissemination of the ideology of clericalism, for what they are destroying the existing progressive secular educational systems. The authoritarian powers are trying to justify this reversal off with far-fetched judgments that 'the Liberal idea is outdated' because 'due to liberalism population and the elite have been divided', 'the governing elites broke away from the people', etc. [2]. In fact, all these allegations are designed to mislead people and, at the same time, they demonstrate full ignorance of the 'authorities' and their adepts both the realities in the world, and about the true influence of the ideas of human rights, democracy and the rule of law to humankind's progress. But how could they know about, if there is not any obligatory for the citizens courses on the theories of human and peoples ' rights, democracy and the rule of law even in the University programs? Connecting education systems with the state order, De Tracy [3] wrote: "Those governments which support themselves by false ideas, should not venture to give to their subjects a very solid education; that those which require to keep certain classes in a state of degradation and oppression, should not permit them to obtain instruction; and that those governments only which are founded on reason, can desire that education should be solid, profound, and generally diffused" [3].The notions 'liberalism' as well as 'socialism', 'communism', etc. is used as shorthand for all ideologies and practices for modernization the world order with a focus on specific aspects of life. Speaking figuratively, liberalism can be called the forefather of all progressive movements.

Classical liberalism arose as a protest absolutism, tyranny and champions for democratic republicanism, political freedoms, democracy and human rights, equality of citizens before the law. In contrast to the State-centrist and absolutist concepts of world order and public life, the prominent thinkers [1-12] put forward and substantiated the concept that people (civil society) constitute the State as one of his institutions for solving all those tasks of the society 
its members are unable to solve individually. The functionaries of the State are elected by people, must serve them and the society, and as such it should be under the strict control.

The true liberals were the most convinced and consistent republicans. So, Harrington [4] defined Republic as a Commonwealth of equal citizens or the rule of the people. A man who cannot live in their own discretion, Harrington [4] believed, becomes a servant, and the one, living in its own discretion, is a free man. Where a person cannot live in its own discretion, there is a monarchy or aristocracy. Where people live in their own discretion, they govern themselves and there is democracy. The society of free people can only be in a democracy, as well as democracy is possible only in a society of free people. Generalizing all known experience of the political systems, Harrington [4] concluded that the governance is an art, by which one person or several people, subduing the town or the people, manage them in their own interests. Laws are adopted in this case in accordance with the interests of that person or that group of people; such a state can be called the empire of man, but not an empire of laws [5]. The law is the will of people with its engine-interest. The interest of the people is common, and it coincides with the public interest; where the public interest rules, there the law rules, not a man. The interest of the King or a private party is a private interest. Where private interest rules, there is the rule of a man, not the rule of law.

Many ideas of the democratic order in England had emerged during the English revolution and after it. Milton [7] [7] resolutely rebuffed the church dogmas that Jesus did leave his Vice Regent on the Earth, and such Vice Regents in States are the Kings and, in the Church, the Pope. Church and State should be separated and completely independent from each other, the right to freedom of conscience to be guaranteed to everyone. Union of the Church and the State defames purity of religion and is dangerous for civil liberties, Milton [7] wrote in his treatise 'On civil power in ecclesiastical matters' (1659). Society must tolerate all Protestant sects, as well as eliminate the economic basis the clergy's power by abolition ecclesiastical tithes. In his pamphlet "The positions of the Kings and judges» Milton [7] wrote: "As the King or judge get their power from people and, above all ... for the good of the people, not their own, people have the right to elect or reject, abandon, or dethrone him, although he was not a tyrant, as often as it deems fit, simply by virtue of the freedoms and the right of the freeborn people". In another pamphlet Milton [7] repeated: "If it happens that the tyrant takes possession of scepter, he immediately finds his spearmen, his peaks and guns".

In 1659-beg. 1660 new discussions occurred in England on the ways to further development of the country. The English society had been divided into three currents: supporters of the Republic, the supporters of constitutional monarchy and supporters of absolute monarchy. In this critical situation, Milton [7]'s contemporary Richvord wrote: "When the deceived crowd was returning to slavery", the almost blinded thinker appealed to reason and justice, which had not defeated [6].
For Milton [7] a Republic was the State of free and equal people without personal power. Discussing the draft of constitutional changes in England after Cromwell' death, Milton [7] offered to find the most correct answers to the questions: Would it not be safer for people to have such a person with a Council, vested with authority only to enforce laws, and all legislative power entrust to the House of representatives? Wouldn't it be fairer to elect such a man for a period of one to two years and make him and his Council responsible for their activity before the Parliament? Will not it be more responsible and less danger for the nation than the hereditary monarchy, well known for its religious intolerance, lack of civic freedom and spiritual servility and known to all the depravity of the yard [7].

In the Republic of Milton [7], the supreme power has rested with the Council, comprising from the most capable persons elected by the people. All officials should perceive their work as public service and do not receive any salary for it. Milton [7] called freedom a wetnurse of all great talents; he advocated for the freedom to thoughts and to judge in own conscience. General for all humankind divine law - the of nature, being the Law of lows, must govern in society. Only in such society dignity will flourish and multiply happiness. Milton [7] considered referendums on legislation and public control as the obligatory means against venality.

Thus, John Milton [7] had formulated three fundamental rules of democracy: the rule (sovereignty) of the people, the supreme representative power and the Federation as a form of the Commonwealth. As an answer the fierce resistance of monarchists, Milton [7] wrote I proposed the century to throw the shackles of oppression, to live according to the example of the former liberty, and was immediately surrounded by wild crowd of Cuckoos, owls, dogs, monkeys and donkeys.

Among advocates of freedom and democracy Algernon Sidney [10] (1623-1683) rightly takes the most eminent place. Thomas Jefferson [9] called him together with John Locke two sources of the American understanding of political freedom and the rights of humankind [9, p. 479]. Sidney [10] was an ardent supporter of democratic republic. He is often compared with Socrates, condemned to death for alleged corruption of youth. Socrates was a moral philosopher, while Sidney [10] -a political one, also sentenced to death for his views. Both sentences were found to be erroneous, but alas, after their execution. Sidney [10] participated in the civil war for the Republic with the rank of Colonel, was elected a member of Parliament and a member of the Jury for trial of the King. But he refused to obey 0 . Cromwell, who's regime he considered as tyrannical. After the restoration he had to tramp around Europe, pursued by the King's agents, trying to kill him.

Sidney [10] together W. Penn elaborated drafts of the Constitution of the colony of Pennsylvania and religious freedoms. In 1680, in the highest point of the struggle between Whigs (Liberals) and Tori, he wrote the treatise 'Discourse concerning the Government', which argued that people by their natural right to freedom elect their rulers. The Government which enjoys the 
support of the majority of people is the best. Protection of human rights, promotion of the excellence and punishment of the evils are its main calling. "If public safety is ensured, freedom also is ensured: Justice rules, dignity is promoted, any vice is suppressed, the true interests of the people are moving forward and the goals of the government are achieved", Sidney [10] believed. The State's rights should be limited to the objectives for which it was established. As the States are established by people to address their specific challenges, they have the right to overthrow them, when it becomes destructive of these ends, the People have the right to alter or to abolish it, and to institute new one [10].

In short the political philosophy of A. Sidney [10] postulated: All people are created equal; they are endowed with some natural rights; people establish the States (Governments) to protect their rights and freedom; the power of governments rests on the consent of the governed; and people have the right to revolution.

As it is known, all these ideas were reflected in 'The Declaration of independence' and recognized in the following centuries as the fundamental principles of democracy. Jefferson [9], Madison [12] and some other 'Founding Fathers' of the United States began to implement ideas of democratic republicanism in practice.

\section{Conclusion}

Not once in the socio-political life happened that the ranks of popular and enjoying the people's tremendous trust and support movements have infiltrated (probably, and will penetrate in the future), with quite different goals their mortal enemies. In Latin America, this phenomenon has been called "Entrizmo". As the percentage of the 'enemies' increased, changed the ratio of the true fighters for progressive ideas and participating in their ranks to prevent them, and therefore the trends of the movements and political parties. There occurs a substitution of the ideas, slogans, but keeping the popular "labels". Many of those who calls themselves liberals, democrats, communists, nationalists, patriots, etc., including almost all the current 'governing elite' of the former socialist countries, indeed are the bearers of these masks, but with completely opposing and undermining the efforts of progressive forces goals.

\section{References}

1. Churchill

2. Interview with Vladimir Putin. Financial Times, Russia.

3. De Tracy D, Commentary and review of Montesquieu's Spirit of Laws. Philadelphia, USA, P. 148.

4. Harrington J (2010) The Oceana and other works (1656). Liberty Fund. Indianapolis, USA, pp. 99-110.

5. Ibid. P. 89

6. Rikvord E (1947) Milton as a revolutionary thinker. Hill K(eds), The English Revolution, p. 186.

7. Milton J (1915) Mordecai Clark. New haven, Yale University Press, USA, p.22.

8. Rykvord E (1984) Milton as a revolutionary thinker. Hill K. The English Revolution, USA, p. 186.H

9. Jefferson T, Writings. New York, USA.

10. Sidney A (2001) Discourses Concerning Government. Indianapolis, USA, p. 205.

11. Mutagirov DZ (2013) Jeffersonian Democracy: The Unity of Theory and Practice. Politex 9(3): 272-290.

12. Mutagirov VZ (2014) Democracy as a universal value. M Logos, pp. 221243. 